\title{
IMPLEMENTASI PROGRAM PENDIDIKAN KARAKTER DI SEKOLAH DASAR NEGERI LAWANGGINTUNG 01 KOTA BOGOR
}

\author{
Ravhi Pertiwi $^{\text {a) }}$, Yudhie Suchyadi ${ }^{\text {a) }}$, Sumardi ${ }^{\text {a) }}$, Rukmini $^{\text {a) }}$ \\ ${ }^{a}$ Universitas Pakuan, Bogor, Indonesia \\ e-mail korespondensi : ydhie.schyadi@gmail.com
}

diterima: 29 Januari 2019; direvisi: 16 Februari 2019; disetujui: 26 Februari 2019

\begin{abstract}
This research is use qualitative descriptive approach. The purpose of this research is to describe how the planning and the implementation of charactereducation in SDN Lawanggintung 01. The result of this research is the planningof chacarcter education is start with analyst how the condition and potency in this school to decide the value of character which will be implemented there are religious, nationalis, indeoendent, discipline, like to read, appreciate achievement, environmental care.Integrating the main character and values matched with the standards of com-petence and basic competence, suitability with the material. The implementation of character education was realized through teach character values in layers of artefacts on school culture with provide the infrastructure that will support the character education program. The program of character education was designed to build student character through the habituation at school who can make student familiarize by theirselves about character values which has been planned in school. From the result of the research above can be concluded that the implementation of character education in SDN Lawanggintung 01 has been implemented well from the planning to the implementation.
\end{abstract}

Keywords: character educaton, student character.

\section{PENDAHULUAN}

Pendidikan adalah faktor yang paling penting dan prioritas utama yang membutuh-kan perhatian serius dari semua pihak, karena pendidikan adalah penentu kemajuan bangsa di masa depan [1]. Tujuan dan cita-cita nasional, untuk kehidupan intelektual bangsa terkandung dalam UUD 1945. Pemerintah bersama masyarakat terus mencari pengembangan pendidikan demi terwujudnya bangsa yang mandiri, unggul dan siap menghadapi dunia globalisasi [2]. Dunia pendidikan dewasa ini banyak ditemukan berbagai masalah seperti permasalahan merosotnya karakter peserta didik. Hal ini menandakan bahwa karakter generasi muda saat ini sudah mulai rusak dan belum adanya pula penanganan secara tuntas mengenai permasalahan ini. Salah satu cara untuk meminimalisasi peristiwa-peristiwa tersebut ialah melalui penerapan pendidikan karakter. Salah satu hal yang sangat mendukung kemajuan pendidikan karakter yaitu melalui budaya sekolah. Budaya sekolah yang diprogramkan dengan baik akan mendukung tingkat keberhasilan dari program pendidikan karakter.

Hasil dokumentasi yang telah dilakukan bahwa SDN Lawanggintung 01 dirujuk untuk menjadi contoh sekolah yang menerapkan pendidikan karakter di Kota Bogor oleh karena itu sekolah ini memiliki komitmen dalam membangun budaya berkarakter. Hal tersebut terlihat dari visi misi sekolah yang mencerminkan budaya berkarakter dan nilai-nilai yang berusaha di canangkan di SDN Lawanggintung 01 sangat berkomitmen pada nilai karakter yang positif.

SDN Lawanggintung 01 berupaya mengembangkan pendidikan karakter melalui aktivitas pembiasaan untuk seluruh siswa di sekolah.. Hal tersebut tampak pada keseharian mulai siswa datang ke sekolah sampai pulang. Contohnya antara lain kegiatan jabat tangan kepada guru, berbaris rapi sebelum masuk kelas, berdoa sebelum dan sesudah kegiatan belajar mengajar, memberi salam, piket kelas, membuang sampah pada tempatnya, terbiasa tidak mencontek, melakukan penghormatan disetiap awal jam pelajaran, selain itu masih terdapat beberapa dinamika pendidikan implementasi dalam penanaman nilai-nilai karakter pada budaya sekolah yang perlu digali lebih dalam oleh peneliti. Dengan mengimplementasikan pendidikan karakter, komitmen, dan fokus dalam membina karakter sehingga sekolah meraih berbagai kejuaran. Dari hasil obserbasi tersebut peneliti tertarik untuk menganalisis bagaimana perencanaan serta implementasi program pendidikan karakter melalui budaya sekolah di SDN Lawanggintung 01 .

Suchyadi mengungkapkan bahwa perbedaan karakter anak dengan kebutuhan yang beragam akan membutuhkan kemampuan guru untuk menggabungkan berbagai kemampuan dan bakat masing-masing anak [3]. Megawangi dalam Kesuma [4] mengatakan bahwa pendidikan karakter ialah suatu usaha yang dengan sadar dilakukan untuk dapat mendidik anak-anak ataupun peserta didik agar mereka dapat memutuskan suatu keputusan yang bijak dan juga mengimplemen-tasikanya ke dalam kehidupan sehari-hari, dengan begitu mereka (anak-anak atau peserta didik) dapat memerikan suatu kontribusi yang lebih positif kepada lingkunga sekitarnya. Pola asuh orang tua adalah kebiasaan yang biasa dilakukan oleh ayah dan ibu yang diterapkan kepada anak dalam perkembangan-nya, berbagai bentuk pola asuh dapat diterapkan kepada anak, namun sangat bijak apabila pola asuh orang tua yang akan diberikan kepada anak disesuaikan dengan usia dan kemampuan anak [5].

Selain itu, Aqib [6] mengatakan bahwa Pendidikan karakter harus dapat menanamkan suatu kebiasaan tentang segala hal yang akan dipilih untuk dilakukan oleh setiap anaknya. Hal ini termasuk bagaimana anak dapat memilih baik tidanya suatu hal. 
Sedangkan Samani [7] juga mengemukakan pendapatnya bahwa penindikan karakter dapat dimaknai bahwa kita dapat memberikan suatu tuntutan untuk seluruh anak maupun siswa agar mereka dapat menjadi manusia seutuhnya yang juga memiliki karakter baik dalam beberapa dimensi seperti dimensi hati, raga, piker, rasa serta karsa.

Aqib [6] berpendapat bahwa inti dari pendidikan karakter ialah mempunyai tujuan untuk membentuk sikap bersaing sehat, kuat, serta memiliki akhlak mulia, bersikap menghargai, bermoral yang baik, mau saling bergotong royong, nasionals, bergerak dan berorientasi pada IPTEK yang dijiwai oleh iman dan takwa kepada Tuhan YME dengan berdasarkan pada Pedoman negara.

Sedangkan Amri [8] berpendapat bahwa dengan adanya Pendidikan karakter mutu dan hasil pendidikan di setiap sekolah selalu mengarah pada terbentuknya karakter dan memiliki akhlak mulia secara sempurna dan seimbang. Senada dengan pengertian tersebut Barnawi [9] menyatakan bahwa tujuan pendidikan karakter adalah agar terwujudnya insan yang memiliki ilmu dan juga berkaraker positif. Karakter yang diharapkan tidak tercerabut dari budaya asli Indonesia sebagai perwujudan nasionals dan sarat akan muatan agama (religius).

Program penidikan karakter dapat dilakukan dalam beberapa tahapan sebagai berikut:

1) Integrasi dalam mata pelajaran

Pengembangan nilai-nilai karakter harus dimasukan dalam setiap setiap mata pelajaran dan dicantumkan dalam silabus dan RPP (Rencana Pelaksanaan Pembelajaran).

2) Integrasi dalam budaya sekolah

Kurniawan [10] berpendapat bahwa sEmua warga sekolah akan terdorong untuk melakukan kerjasama yang didasarkan dengan rasa saling percaya apabila sekolh menerpkan budaya yang positif, selain itu budaya sekolah yang positif dapat memberikan kesempatan agar terlaksananya pembaruan di sekolah dengan harapan mendapatkan hasil terbaik.

Samani [7] mngungkapkan bahwa ada empat hal upaya yang dapat ditempuh untuk mengembangka budaya sekolah sebagai berikut:

(1) Kegiatan rutin adalah kegiatan diprogramkan oleh sekolah dengan metode pengulangan dan konstan yang dilakukan sesuai jadwal. seperti kegiatan upacara bendera yang dilakukan setiap hari senin, piket kelas setiap hari secara bergantian, shalat berjamaah baik solat sunat maupun solat wajib, berdoa sebelum dan setelah pelajaran dimulai, dan lain sebagainya.

(2) Kegiatan spontan yaitu kegiatan yang dilakukan saat itu juga, pada waktu ataupun keadaan tertentu, misalnya menjenguk teman yang sedang sakit, mengumpulkan sumbangan bagi teman yang sedang mendapatkan musibah dan lain sebagainya.

(3) Keteladanan ditimbulkan melalui cara guru ataupun staf kependidikan yang lain memberikan teladan berupa perilaku positif yang nantinya akan dilihat dan akna ditiru oleh siswany misalnya kerapihan dalam berpakaian, kedisiplinan waktu, tertib dan teratur, saling peduli dan saling menyayangi, dan lain sebagainya.

(4) Pengkondisian, sekolah menciptakan kondisi dan suasana yang nyaman yang dapat mendukung terlaksananya program pendidikan karakter, seperti menata ruangan dengan rapi, toilet dalam kondisi bersih, penyediaan tempat sampah, halaman sekolah yang rindang dan asri dan lain sebagainya.

3) Integrasi melalui ekstrakurikuler

Syarbini [11] kegiatan ekstrakurikuler merupakan kegiatan diluar waktu kbm yang bertujuan untuk dapat mengembangkan dan menyalkurkan minat serta bakat setiap peserta didik. Dalam kegiatan ekstrakurikuler, peserta didik diajarkan berbagai macam keterampilan yang tidak hanya melibatkan pengetahuan saja tapi juga rasa maupun karsa.

Mulyasa [12] berpendapat bahwa implementasi akan menuntut kerja tim yang optimal diantara para guru maupun tenaga kependidikan lainya, sehingga memerlukan pembelajaran yang berbentuk tim, dan menuntutut kekompakan pada setiap anggota tim tersebut.

Sumaatmadja dalam Amri [8] berpendapat bahwa pendidikan nilai ialah upaya untuk mewujudkan manusia yang terdidik dengan baik. Termasuk didalamnya pada iman akhlak serta ilmunuya. Pemerintah selama ini sudah mulai mengembangkan dan mengimplementasikan nilai-nilai pembentuk karakter dengan memberikan kebebasan kepada satuan pendidikan untuk memilih nilai prioritasnya masingmaisng.

\section{METODE PENELITIAN}

Penelitian ini berlokasi di SDN Lawanggintung 01, yang beralamat di Jl. Lawang Gintung No. 22, Lawanggintung, Bogor Selatan, Kota Bogor, Jawa Barat, 16133. Observasi awal dilakukan pada bulan November 2017. Pengumpulan data dilapangan dilakukan pada bulan Maret 2018. Kepala sekolah merupakan subjek utama di dalam penelitian sedangkan subyek pendukungnya adalah peserta didik serta guru di SDN Lawanggintung 01 .

Metode Prosedur Penelitian dilakukan dengan pendekatan kualitatif merupakan pendekatan yang peneliti pilih dalam penelitian ini yang bersifat analisis deskriptif. Karena dengan menggunakan pendekatan kualitatif peneliti dapat memahami fenomena-fenomena yangada untuk mengumpulkan fakta di lapangan yang diperlukan peneliti berkaitan dengan fokus penelitian.

Metode penelitian ini dimaksudkan untuk mencatat, menganalisis, dan juga mendeskripsikan keadaan yang ada dan sedang berlangsung tersebut ke dalam berbagai bahasa verbal. Ada dua tahap yang dilakukan peneliti, yaitu tahap observasi lapangan dengan mengamati kegiatan siswa di sekolah dan tahap selanjutnya yaitu melakukan wawancara. 


\section{HASIL DAN PEMBAHASAN}

Budaya sekolah di SDN Lawanggintung 01 dapat diidentifikasikan dari setiap lapisan budaya sekolah yang terbagi dua yaitu lapisan yang dapat diamati dan lapisan yang tersembunyi atau lapisan yang tidak dapat diamati.

\section{Lapisan Nilai dan Keyakinan}

Lapisan nilai dan keyakinan di SDN Lawanggintung 01 dapat dipahami dari pendidikan karakter yang diprogramkan dalam kurikulum di SDN Lawanggintung 01 yang difokuskan pada pokok pembinaan karakter, sebagai berikut: Keagamaan di Sekolah; Pembinaan Nasionalisme; Pembinaan kemandirian; Pembinaan kedisiplinan; Pembiasaan membaca; Sikap menghargai prestasi; Peduli lingkungan

\section{Lapisan Artifak}

a. Perwujudan fisik

Perwujudan fisik dari budaya sekolah di SDN Lawanggintung 01 dapat dilihat dari fasilitas sekolah serta dokumen yang dimiliki oleh sekolah. SDN Lawanggintung 01 juga menyediakan fasilitas pemilahan sampah. Tempat pembuangan sampah terbagi menjadi 2 yaitu tempat sampah untuk sampah organic dan untuk sampah anorganik. Selain itu, setiap kelas juga memiliki fasilitas kebersihan berupa sapu, lap pel dan kemoceng. Sumber air bersih didapatkan dari PDAM Selain itu terdapat juga madding sekolah, madding kelas, dan fasilitas buku-buku bacaan.

Di luar ruangan yang ada di SDN Lawanggintung 01, tertata taman sekolah dengan rapi di depan ruangan-ruangan kelas. Pada lapangan upacara tersebut juga terpasang tiang untuk mengibarkan bendera Merah Putih setiap harinya.

\section{b. Perwujudan perilaku}

Perwujudan perilaku dalam budaya sekolah di SDN Lawanggintung 01 ini direncanakan dalam aktivitas-aktivitas nyata yang diprogramkan oleh sekolah. Aktivitas-aktivitas tersebut dilaksanakan baik pada waktu pembelajaran efektif ataupun kegiatan tambahan di luar jam pembelajaran. Kegiatan tersebut diantaranya yaitu kegiatan upacara bendera, merayakan hari besar kegamaan, kegiatan ekstrakurikuler, pembiasaan-pembiasaan kemandirian seperti mencucui tempat bekal sendiri, pembiasaan kedisiplinan, penghafalan surat-surat pendek dan surat yasin, pembiasaan menyanyikan lagu nasional sebelum memulai pembelajaan, pembiasaan berjabat tangan, pembiasaan piket kelas setiap hari, dan juga pembelajaran muatan local seperti bahasa sunda.

Berdasarkan hasil penelitian mengenai perencanaan pendidikan karakter melalui budaya sekolah, dapat dimaknai bahwa SD Negeri Lawanggintung 01 merencanakan pendidikan karakter secara sistematis dan terprogram. Perencanaan tersebut berupa rancangan program pendidikan karakter yang terprogram dalam kurikulum sekolah termasuk nilai-nilai karakter yang menjiwai. Selain itu juga disiapkan dukungan sarana dan prasarana pendukung program serta sosialisasi program kepada warga sekolah dan orang tua siswa.
Karakteristik dari budaya sekolah di SDN Lawanggintung 01 dalam kaitannnya dengan pendidikan karakter yaitu dikembangkan melalui program-program yang secara sengaja dirancang dan didasari oleh 7 nilai-nilai karakter utama. 7 nilai karakter tersebut yaitu nilai religius, nasionalis, mandiri disiplin, gemar membaca, menghargai prestasi, dan peduli lingkungan. Sebagai suatu lembaga pendidikan, SDN Lawanggintung 01 memodifikasi nilainilai karakter tersebut sesuai kebutuhan dan kondisi budaya sekolah.

\section{Perencanaan program pendidikan karakter melalui budaya sekolah di SDN Lawanggintung 01}

Perencanaan pendidikan karakter melalui budaya sekolah di SDN Lawanggintung 01 pada dasarnya berlangsung dalam beberapa tahap. Tahap-tahap tersebut diuraiakan berikut ini:

a. Dilakukan analisis konteks terhadap kondisi dan potensi yang dimiliki sekolah untuk menetapkan nilai-nilai karakter yang akan dikembangkan pada satuan pendidikan tersebut.

b. Penyusunan program dan dokumen perencanaan berupa tata tertib serta kurikulum sekolah.

c. Sosialisasi kebijakan baik kepada guru, karyawan, siswa, maupun orang tua siswa.

d. Perencanaan pengkondisian dilaksanakan terkait dengan penyediaan fasilitas sekolah, pemberian keteladanan oleh guru, dan penciptaan suasana sekolah yang nyaman untuk belajar.

\section{Implementasi program pendidikan karakter melalui budaya sekolah di SDN Lawanggintung 01}

Samani [7] menyatakan bahwa pendidikan karakter yang efektif harus dilengkapi dengan kurikulum akademis yang bermakna dan menantang, yang menghargai semua pembelajar dan membantu mereka untuk mencapai sukses. Kurikulum SDN Lawanggintung 01 memprioritaskan tujuh nilai karakter dalam pembinaannya dalam budaya sekolah. Implementasi dari nilai-nilai karakter tersebut dilakukan dalam beberapa program sekolah baik yang termuat dalam kurikulum maupun yang hanya dibiasakan oleh semua warga sekolah.

\section{a. Implementasi Nilai Religius Melalui Budaya Sekolah}

Samani [7] bahwa semua nilai yang ditanamkan harus dijiwai oleh iman dan takwa kepada Tuhan Yang Maha Esa berdasarkan pancasila. Pembinaan nilai religius pada kultur sekolah di SDN Lawanggintung 01 dapat digambarkan pada proses aktivitas-aktivitas siswa di sekolah. Setiap pagi siswa disambut oleh guru, siswa akan menyalami kepala sekolah dan guru piket di depan pintu gerbang sekolah. Pembiasaan ini secara tidak langsung telah mendidik siswa untuk terbiasa menghormati orang yang lebih tua. Kemudian sebelum melakukan pembelajaran semua siswa bersama-sama membaca asmaulhusna serta surat-surat pendek.

Pembelajaran di kelas juga mengintegrasikan nilai religius dalam pembelajarannya. Melalui aktivitas-aktivitas pembelajaran keagamaan, siswa dilatih untuk memahami 
dan mempraktikkan ilmu agama mereka. Secara otomatis keyakinan agama siswa semakin diperkuat dan menjadikan siswa yang berakhlak mulia.

Aktivitas lain yang mencerminkan nilai religius yaitu pengumpulan infaq yang dilakukan setiap hari jumat, melakukan solat dhuha berjamaah setiap hari jumat dan juga melakukan siraman rohani sebelum pembelajaran dimulai pada hari jumat. Selain itu diadakan juga perayaan hari besar keagamaan seperti perayaan isra mi'raj, perayaan idulqurban dan idul fitri serta dilakukan pengumpulan dan penyaluran zakat. Dalam aktivitas tersebut perwujudan sikap toleransi ditunjukkan melalui penghormatan dari siswa non-Islam yang jumlahnya sangat sedikit. Meskipun kegiatan atau perayaan hari besar agama non-Islam tidak banyak diprogramkan di SDN Lawanggintung 01 , tetapi toleransi beragama yang dilakukan oleh siswa mayoritas yang beragama Islam sudah dilaksanakan. Terbukti dalam interaksi siswa di luar kegiatan keagamaan tetap berlangsung dengan baik tanpa membeda-bedakan agama.

\section{b. Implementasi Nilai Nasionalis Melalui Budaya Sekolah di SDN Lawanggintung 01}

Aisyah dalam penelitianya yang berjudul "Implementasi Pendidikan Karakter Di SDIT Nurul Ilmi Kota Jambi" berpendapat bahwa cinta tanah air (Nasionalisme) yaitu cara berpikir, bersikap, dan berbuat yang menunjukkan kesetiaan, kepedulian, dan penghargaan yang tinggi terhadap bahasa, lingkungan fisik, sosial, budaya, ekonomi, dan politik bangsa.

Nilai nasionalis di SDN Lawanggintung 01 dibentuk melalui pembiasaan program-program yang telah direncanakan. Salah satu program yang dilaksanakan yaitu upacara bendera setiap hari Senin dan hari besar nasional. Melalui upacara bendera tersebut, siswa terbiasa untuk menghormati simbol negara berupa Bendera Merah Putih serta memahami Pancasila dan UUD 1945. SDN Lawanggintung 01 juga selalu memperingati dan merayakan hari nasional, seperti yang telah dilaksanakan pada tanggal 21 April 2018 SDN Lawanggintung 01 memeriahkan Hari Kartini dengan melakukan festival anak berkeliling di sekitaran SD tersebut dengan menggunakan baju-baju adat setelah itu para siswa melakukan lomba fashion show. Untuk memeriahkanya lagi, SDN Lawanggintung 01 juga mengadakan lomba kebersihan kelas..

Selain itu, semangat nasionalisme juga ditumbuhkan melalui kegiatan menyanyikan Lagu Kebangsaan "Indonesia Raya". Dari hasil observasi yang telah peneliti lakukan, setiap pagi hari sebelum kegiatan pembelajaran dimulai, semua murid menyanyikan lagu "Indonesia Raya" setelah itu semua siswa dan guru melakukan penghormatan kepada bendera merah putih yang telah disediakan di depan kelas. Pembiasaaan tersebut bertujuan untuk melatih siswa dalam menghargai jasa para pahlawan sehingga mereka semakin bersemangat untuk belajar dan memajukan bangsa di masa yang akan datang.

\section{c. Implementasi Nilai Mandiri Melalui Budaya Sekolah di SDN Lawanggintung 01}

Muslich [13] menyatakan bahwa nilai karakter mandiri muncul dari penanaman nilai-nilai humanisasi dan liberasi. Dengan penanaman bahwa tiap-tiap manusia dan bangsa memiliki potensi dan sama-sama subjek kehidupan, maka ia tidak akan membenarkan adanya penindasan sesama manusia. Melalui observasi dan wawancara yang peneliti lakukan, SDN Lawanggintung menanamkan nilai mandiri kepada siswa melalui peraturan seperti wajib membawa bekal dan mencuci kotak bekal masing-masing.

Selain program wajib membawa bekal, setiap siswa diwajibkan melakukan piket kelas setiap hari. Setiap kelas mempunyai jadwal piketnya masing-masing. Setelah pembelajaran selesai maka siswa yang mendapatkan giliran piket wajib merapihkan kelas dan merapihkan buku yang terdapat didepan kelas. Apabila siswa tidak melakukan piket, maka siswa tersebut harus membayar denda kepada bendahara, hasil uang denda tersebut akan digunakan oleh bendahara untuk memenuhi keperluan kelas seperti alat-alat kebersihan, dekorasi kelas ataupun untuk menjenguk teman kelasnya yang sakit.

\section{d. Implementasi Nilai Disiplin Melalui Budaya Sekolah di SDN Lawanggintung 01}

Pusat Kurikulum Depdiknas [14] menyatakan bahwa nilai disiplin merupakan Tindakan yang menunjukkan perilaku tertib dan patuh pada berbagai ketentuan dan peraturan. Di SDN Lawanggintung 01, nilai disiplin menjadi motor penggerak terimplementasinya nilai-nilai karakter yang lain. Budaya sekolah yang dibangun di SDN Lawanggintung 01 mendorong siswa untuk taat terhadap tata tertib sekolah dan melalui edukasi akan semakin memantapkan siswa untuk menyadari esensi manfaat dari tidak melanggar tata tertib sekolah.

Gerbang sekolah ditutup 30 menit sebelum pembelajaran dimulai hal ini dilakukan untuk melatih kedisiplinan siswa terhadap waktu. Selain terdapat beberapa tata tertib yang sifatnya memaksa. Apabila terdapat siswa yang melanggar tata tertib satu kali siswa akan diberikan teguran namun apabila sudah lebih dari 3 kali maka pihak sekolah memanggil orangtua siswa tersebut untuk dating ke sekolah dan memberikan penjelasan mengenai pelanggaran yang dilakukan oleh anaknya.

Selain disiplin waktu, siswa maupun guru di SDN Lawanggintung 01 juga sangat patuh terhadap tata tertib berpakaian. Selama observasi peneliti tidak pernah melihat siswa maupun guru yang melanggar aturan berpakaian tersebut.

\section{e. Implementasi Nilai Gemar Membaca Melalui Budaya Sekolah}

Pusat Kurikulum Depdiknas [14] nilai gemar membaca merupakan kebiasaan menyediakan waktu untuk membaca berbagai bacaan yang memberikan kebajikan bagi dirinya. SDN Lawanggintung 01 membuat program membaca buku yang dinamakan program literasi. Pada saat obeservasi dilaksanakan, peneliti melihat setiap anak sebelum pembelajaran dimulai diwajibkan untuk membaca buku yang telah disediakan disetiap kelas. Siswa dengan 
bersemangat ingin membaca buku-buku tersebut. Namun kegiatan ini bukan hanya membaca saja, melainkan siswa juga harus menuliskan informasi penting yangterdapat dalam bukiu bacaan yangtelah mereka baca.

\section{f. Implementasi Nilai menghargai Prestasi Melalui Budaya Sekolah di SDN Lawanggintung 01}

Hasil studi Dr. Marvin Berkowitz dari University of Missouri- St. Louis dalam Muslich [13] menunjunjukan peningkatan motivasi siswa sekolah dalam meraih prestasi akademik pada seklah-sekolah yang menerapkan pendidikan karakter. Kelas-kelas yang secara komprehensif terlibat dalam pendidikan karakter menunjukan adanya penurunan drastic pada perilaku negatif siswa yang dapat menghambat keberhasilan akademik.

Dari hasil observasi yang telah peneliti lakukan, peneliti melihat bahwa setiap kelas memiliki kelompok belajar tertentu. Kelompok belajar ini dipilih secara heterogen yaitu siswa yang cerdas dan aktiv dalam proses pembelajaran dan siswa yang masih memerlukan bimbingan. Di dalam kelompok ini, siswa yang memiliki lebih cerdas membantu temanya dalam proses pembelajaran maupun dalam mengerjakan tugas.Selain itu, SDN Lawanggintung 01 selalu memfasilitasi siswanya untuk mengikuti kegiatan lomba.

\section{g. Implementasi Nilai Peduli Lingkungan Melalui Budaya Sekolah di SDN Lawanggintung 01}

Dari hasil observasi di SDN Lawanggintung 01 terlihat bahwa sekolah ini sangat memperhatikan kadaan lingkunganya. Dapat dilihat dari peraturan sekolah yang mewajibkan siswa untuk membawa bekal hal ini dilakukan untuk mengurangi penggunaan sampah. Selain itu di sekolah ini disediakan banyak sekali tempat sampah yang sudah dipisahkan antara sampah organic dan unorganik. Disetiap kelas juga disediakan alat-alat kebersian dalam kondisi yang baik dan mencukupi. Kesadaran peghuni sekolah akan kebersihan lingkungan pun sangat baik, di sekitar sekolah tidak terlihat sampah yang berserakan.

\section{SIMPULAN}

Program pendidikan karakter melalui budaya sekolah di SDN Lawanggintung 01 pada dasarnya terimplementasi pada dua lapisan yaitu lapisan nilai dan keyakinan serta lapisan artifak. Dalam pengimplementasianya terbagi menjadi 3 tahap yaitu perencanaan program pendidikan karakter, implementasi program pendidikan karakter, serta evaluasi program pendidikan karakter.

Perencanaan pendidikan karakter di SDN Lawanggintung 01 diawali dengan menganilis berbagai kondisi serta potensi yang ada di sekolah untuk dapat menetapkan nilai-nilai karakter mana yang akan dipilih oleh sekolah yaitu nilai religius, nasionalis, mandiri, disiplin, gemar membaca, menghargai prestasi serta peduli lingkungan; penyusunan program-program pendidikan karakter beserta dokumen perencanaan yang sudah termuat di dalam kurikulum sekolah maupun RPP, sosialisasi program pendidikan karakter kepada guru, tenaga administrasi, siswa, dan orang tua siswa; serta perencanaan kondisi pelaksanaan terkait dengan penyediaan fasilitas sekolah untuk menunjang program pendidikankarakter, pemberian keteladanan oleh guru, dan juga penciptaan suasana belajar yang nyaman dan kondusif.

Implementasi program pendidikan karakter melalui budaya sekolah di SDN Lawanggintung 01 terealisasi melalui penanaman nilai-nilai karakter pada lapisan artifak dalam budaya sekolah yaitu melalui penyediaan fasilitasfasilitas yang dapat mendukung berbagai aktivitas penghuni sekolah pada program yang sudah direncanakan maupun yang dibiasakan dalam kehidupan sehari-hari di sekolah. Program-program tersebut didesain untuk dapat membentuk karakter siswa melalui aktivitas-aktivitas di sekitar lingkungan sekolah yang telah dibentuk sedemikian rupa sehingga baik secara sadar maupun tidak sadar siswa telah terbiasa dengan nilai-nilai karakter yang direncanakan oleh sekolah.

\section{REFERENSI}

[1] Y. Suchyadi and Nurjanah, 2018. "Relationship between Principal Supervision in Increasing the Job Satisfaction of Private Junior High School Teachers in East Bogor District," J. Humanit. Soc. Stud., vol. 02, no. 01, pp. 26-29.

[2] Y. Suchyadi, 2017. "Relationship between Work Motivation and Organizational Culture in Enhancing Professional Attitudes of Pakuan University Lecturers," vol. 01, no. 01.

[3] Y. Suchyadi, Y. Ambarsari, and E. Sukmanasa, 2018. "Analysis of Social Interaction of Mentally Retarded Children," J. Humanit. Soc. Stud., vol. 02, no. 02, pp. 17-21.

[4] Kesuma, Dharma dkk. 2011. Pendidikan Karakter: Kajian Teori dan Praktik di Sekolah. Bandung: PT Remaja Rosdakarya

[5] S. Setiarani and Y. Suchyadi, 2018. "Pola Asuh Orang Tua Terhadap Anak Tuna Netra Berprestasi," J. Pendidik. Pengajaran Guru Sekol. Dasar, vol. 01, no. 01, pp. 15-18, 2018.

[6] Aqib, Zaenal dan Amrullah, Ahmad. 2017. Pedoman Pendidikan Budaya dan Karakter Bangsa. Yogyakarta : Gava Media.

[7] Samani, Muchlas dan Hariyanto. 2012. Konsep dan Model Pendidikan Karakter. Bandung: PT Remaja Rosda Karya.

[8] Amri, Sofan., Jauhari, Ahmad dan Elisah, Tatik. 2011. Implementasi Pendidikan Karakter dalam Pembelajaran. Jakarta: PT Prestasi Pustakakarya.

[9] Barnawi dan Arifin. 2012. Strategi dan Kebijakan Pembelajaran Pendidikan Karakter. Yogyakarta: Arruzz Media

[10] Kurniawan, Syamsul. 2013. Pendidikan Karakter. Yogyakarta:Ar-ruzz Media.

[11] Syarbini, Amirulloh. 2012. Buku Pintar Pendidikan Karakter. Jakarta: Prima Pustaka. 
[12] Mulyasa. 2013. Pengembangan Implementasi Kurikulum 2013. Bandung: Remaja Rosdakarya.

[13] Muslich, Masnur. 2011. Pendidikan Karakter: Menjawab Tantangan Krisis Multidimensional. Jakarta: Bumi Aksara.

[14] Kemendiknas. 2010. Desain Induk Pendidikan Karakter. Jakarta: Kemendiknas. 